\title{
Risk Factors and Stress Management Among Hospital Nurses: A Systematic Review
}

\section{Irwan Unggul Widodo and Pujiyanto}

Postgraduate Student Faculty of Public Health, Universitas Indonesia, Depok, Indonesia

\section{Abstract}

Work stress has become one of the most severe health problems in the twenty-first century. Work stress occurs in many workers in the health sector since high levels of individual responsibility make health workers vulnerable to pressure. The amount of work stress experienced by nurses is predicted to continue to increase in the years to come. The is a trend that cannot be ignored because it is very closely related to the safety of both nurses and patients. The purpose of this review is to look the risk factors for work stress in nursing and at the stress-management approaches that are used to address them. The method used was a database search, using keywords, of ProQuest, ScienceDirect, and Google Scholar. The search yielded six studies that met

Corresponding Author: Irwan Unggul Widodo drg.irwan@gmail.com

Pujiyanto

puji_fkm@ui.ac.id

Received: 21 December 2018

Accepted: 23 January 2019

Published: 28 February 2019

Publishing services provided by Knowledge E

(c) Irwan Unggul Widodo and Pujiyanto. This article is

distributed under the terms of the Creative Commons

Attribution License, which permits unrestricted use and redistribution provided that the original author and source are credited.

Selection and Peer-review under the responsibility of the $3 \mathrm{rd}$ IMOPH \& the 1st YSSOPH Conference Committee. the criteria. The results of the review show that the risk factors for stress in various countries are very diverse, ranging from high workload to high anxiety about patients. Work stress arises because of an imbalance between the personality characteristics of employees (personal factors) and the characteristics of their work situation (work environment and organizational factors). Hence, there are two approaches to the management of work stress, namely the individual plan and the regulatory strategy. In some countries, the organizational approach to stress management is very similar to the different approach. Stress management using the personal approach appears to be quite useful in reducing levels of stress and anxiety in nurses, and it can thus contribute to making an individual a better public health nurse.

Keywords: work stress, nurses, risk factors, stress management

\section{Introduction}

Fear is a non-specific response that is a consequence of any external action, situation, or event giving rise to physical and psychological demands on a person. If the stress experienced also involves the organization or company where the person works, it could categorize as work stress [1].

Work stress has become one of the most severe health problems in the twenty-first century. Not only does it have disadvantages for the individual concerning physical and mental morbidity, but it is also detrimental to businesses, governments, and society at large concerning finance. No less than $12 \%$ of gross national product (GNP) in the United States and $10 \%$ in the UK is lost due to turnover related to work stress in 1996 [2]. 
Many health sector workers experience work stress. Having responsibility for the welfare of patients makes health workers particularly vulnerable to pressure [3]. A crosssectional study of 775 health care professionals in Taiwan in 2010 found that $64.4 \%$ of them experienced anxiety, 33.7\% had nightmares, $44.1 \%$ had irritability disorders, $40.8 \%$ experienced headaches, 35\% suffered from insomnia, and $41.4 \%$ had gastrointestinal disorders [4].

Work stress among hospital workers is also common in Indonesia. Work stress from diverse causes was experienced by $44 \%$ of nurses at the inpatient unit at Husada Hospital, Jakarta, 51.5\% of nurses at the International Hospital MH Thamrin, Jakarta, $54 \%$ of nurses at the Hospital PELNI "Petamburan", Jakarta, and $51.2 \%$ of nurses at the intensive care unit and emergency room of Mitra Keluarga Hospital, Bekasi [57].

Work stress experienced by nurses is predicted to continue to increase in the years to come. It is a trend that cannot ignore because it is very closely related to the safety of both nurses and patients [8].

Abraham \& Shanley [9] offer five primary sources of work-related stress in the field of nursing, namely: (1) workload (caring for too many patients, difficulty in maintaining high standards, limited autonomy); (2) staff relationships (conflicts with peers, feeling that other people do not appreciate one's contribution, failure to form a working team with other staff); (3) caring for critically ill patients (using unfamiliar equipment, managing complex procedures, taking responsible and appropriate action); (4) dealing with the treatment and care of patients (disagreement about a program of work, uncertainty about informing the patient or his/her family, challenges in treating difficult or uncooperative patients); and (5) treating patients whose condition does not improve.

There are two types of approach to stress management: individual approaches and organizational approaches. Own criteria include implementing time-management techniques, increasing physical exercise, having relaxation training, and expanding social support networks. Regulatory approaches include improving personnel selection and placement processes, setting realistic goals, redesigning jobs, increasing employee engagement, improving organizational communication, and implementing welfare programs [10].

In the academic field, a lot of research on work stress has been carried out recently by students, faculty, and researchers. The author felt the need to conduct a systematic review of several previous studies to obtain an overview of the characteristics of risk factors and management of nurses' work stress in a variety of countries around the world. It expected that this systematic review would identify risk factors for work-related stress for nurses and discover how stress-management techniques are used to deal with workplace stress. The ultimate aim is to find convenient and comprehensive methods for preventing and handling work stress in nurses. 


\section{Methods}

The present study took the form of a systematic review, following the Preferred Reporting Items for Systematic Reviews and Meta-Analyses (PRISMA) guidelines. An internet search was carried out on online journals from ProQuest, ScienceDirect, and Google Scholar. These sources chose because many articles discuss the use of the internet as a source of information about health. Journals from the period 2012 to 2016 selected to obtain the latest research results. Specific keywords were used to refine the search: work stress, nurses, risk factors, and stress management.

\subsection{Selection of literature}

Studies meeting the following criteria were considered eligible for inclusion in this systematic review: (1) the participants were qualified hospital-based nurses (male or female, of any age); (2) the study had already been peer-reviewed; (3) the study contained qualitative research of some kind; (4) the study had been published; and (5) the study made significant use of the keywords selected for the present study.

\subsection{Data collection}

From the studies that met the selection criteria, the author gathered the following information: (1) general information (author, year of publication, and study site); (2) the study design (method and sample size); and (3) the results of the research.

\subsection{Risk of Bias in individual studies and across studies}

This research focuses on the study of risk factors and management of work stress in hospital-based nurses. The studies to review selected by document title without seeing the research methods used.

\subsection{Selection of studies}

The three databases searched, and a three-stage filtering process was used to exclude unsuitable studies (see Figure 1). 


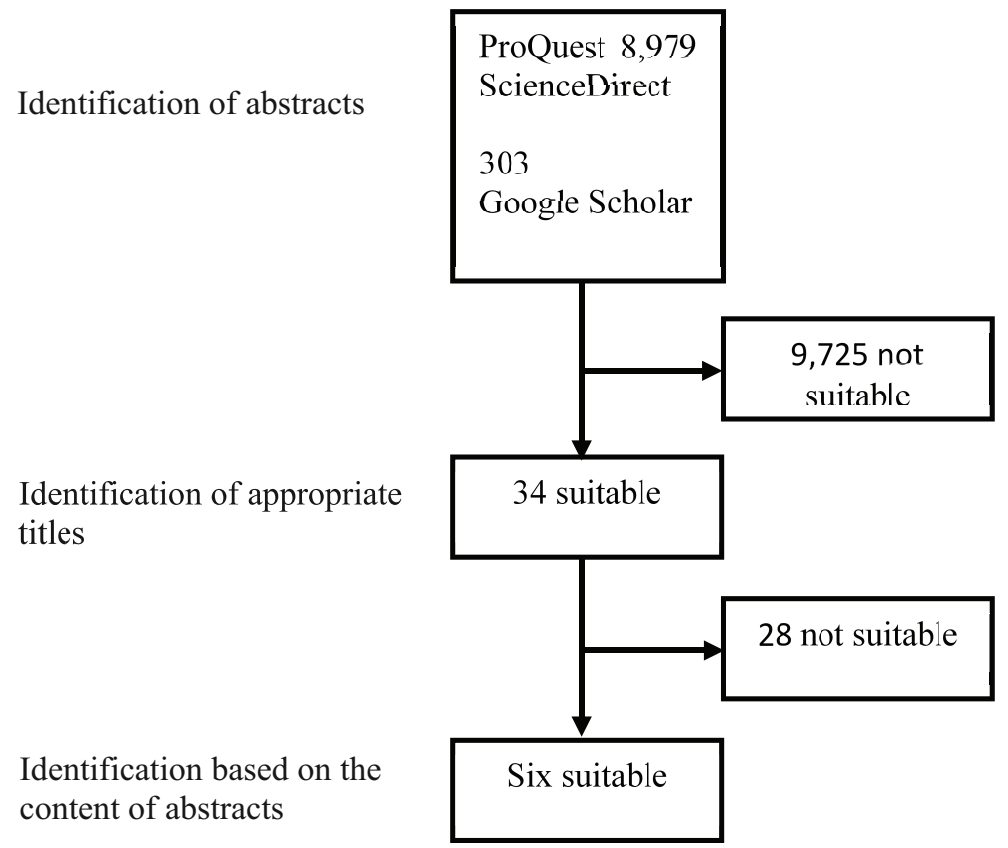

Figure 1: Three-stage filtering process to exclude unsuitable studies.

\section{Results and Discussions}

TABLE 1: Research result journal reviewed.

\begin{tabular}{|c|c|c|c|c|c|}
\hline Title & Year & Location & $\mathbf{n}$ & Methods & Results \\
\hline $\begin{array}{l}\text { Effect of stress } \\
\text { management } \\
\text { intervention on job } \\
\text { stress among nurses } \\
\text { working in critical care } \\
\text { units. [11] }\end{array}$ & 2012 & $\begin{array}{l}\text { Kerala, } \\
\text { India }\end{array}$ & 30 nurses & $\begin{array}{l}\text { Experimental } \\
\text { pre-test post-test } \\
\text { design }\end{array}$ & $\begin{array}{l}\text { The severity of stress } \\
\text { decreased from } 60 \% \text { to } \\
20 \% \text { after post-test } \\
\text { Intervention Stress } \\
\text { Management. }\end{array}$ \\
\hline $\begin{array}{l}\text { Are cognitive-behavioral } \\
\text { interventions effective in } \\
\text { reducing occupational } \\
\text { stress among nurses? } \\
\text { [12] }\end{array}$ & 2012 & $\begin{array}{l}\text { Beer- } \\
\text { Sheva, } \\
\text { Israel }\end{array}$ & 36 nurses & $\begin{array}{l}\text { Experimental } \\
\text { pre-test post-test } \\
\text { design }\end{array}$ & $\begin{array}{l}\text { In T1 (early results), there } \\
\text { was no significant } \\
\text { difference in either } \\
\text { group. In T2 (results after } \\
\text { four months), there were } \\
\text { substantial changes in } \\
\text { the intervention group. }\end{array}$ \\
\hline $\begin{array}{l}\text { Stress dan Mekanisme } \\
\text { Koping Perawat di } \\
\text { Ruang Unit Perawatan } \\
\text { Intensif RSUD RA Kartini } \\
\text { Jepara. [13] }\end{array}$ & 2014 & $\begin{array}{l}\text { Jepara, } \\
\text { Indonesia }\end{array}$ & 33 nurses & $\begin{array}{l}\text { Explorative- } \\
\text { descriptive }\end{array}$ & $\begin{array}{l}\text { Nurses were found to } \\
\text { use a variety of coping } \\
\text { mechanisms for dealing } \\
\text { with stress. }\end{array}$ \\
\hline $\begin{array}{l}\text { Enhancing the resilience } \\
\text { of nurses and midwives: } \\
\text { The pilot of mindfulness- } \\
\text { based program for } \\
\text { increased health, sense } \\
\text { of coherence, and } \\
\text { decreased depression, } \\
\text { anxiety and stress [14] }\end{array}$ & 2013 & $\begin{array}{l}\text { Sydney, } \\
\text { Australia }\end{array}$ & $\begin{array}{l}20 \text { nurses, } \\
25 \\
\text { midwives }\end{array}$ & $\begin{array}{l}\text { Experimental } \\
\text { pre-test post-test } \\
\text { design }\end{array}$ & $\begin{array}{l}\text { MBSR intervention can } \\
\text { effectively improve } \\
\text { individual endurance } \\
\text { and resilience in the } \\
\text { workplace. }\end{array}$ \\
\hline
\end{tabular}




\begin{tabular}{|c|c|c|c|c|c|}
\hline Title & Year & Location & $\mathbf{n}$ & Methods & Results \\
\hline $\begin{array}{l}\text { Enhancing resilience } \\
\text { among new nurses: } \\
\text { Feasibility and efficacy } \\
\text { of a pilot intervention [15] }\end{array}$ & 2015 & $\begin{array}{l}\text { New York, } \\
\text { USA }\end{array}$ & 55 nurses & $\begin{array}{l}\text { Experimental } \\
\text { design: } \\
\text { intervention group } \\
\text { of } 27 \text { nurses, a } \\
\text { control group of } \\
28 \text { nurses }\end{array}$ & $\begin{array}{l}\text { The SMART program } \\
\text { showed promising } \\
\text { results, with an increase } \\
\text { in resiliency and mental } \\
\text { endurance in the } \\
\text { intervention group and a } \\
\text { decrease in the control } \\
\text { group. }\end{array}$ \\
\hline $\begin{array}{l}\text { Self-help stress } \\
\text { management training } \\
\text { through mobile phones: } \\
\text { An experience with } \\
\text { oncology nurses [16] }\end{array}$ & 2013 & Milan, Italy & 30 nurses & $\begin{array}{l}\text { Experimental } \\
\text { design: } \\
\text { intervention group } \\
\text { of } 15 \text { nurses, a } \\
\text { control group of } \\
15 \text { nurses }\end{array}$ & $\begin{array}{l}\text { The study found } \\
\text { improvements in the } \\
\text { experimental group, } \\
\text { including a reduction in } \\
\text { anxiety levels and an } \\
\text { increased ability to cope } \\
\text { with stress. }\end{array}$ \\
\hline
\end{tabular}

The research sample covered different countries in Europe, Asia, North America, and Australasia to discover regional differences in risk factors and the handling of stress in nursing hospitals.

The study in Kerala, India [11] sampled 30 nurses in a Critical Care Unit and used an experimental pre-test post-test design. The instrument used was Intervention Stress Management (IST)-awareness of the existence of work stress, training in mental strength, time management, and muscle relaxation-with interventions carried out periodically for three weeks. The study found that the leading causes of workplace stress were as follows: a sense of empathy for patients, job requirements in general, and workload. The severity of stress decreased from $60 \%$ to $20 \%$ post-test, indicating that the IST was effective in lowering levels of pressure on nurses (significance level of $p<0.001$ ).

The study in Beer-Sheva, Israel [12] sampled 36 nurses and used a pre-test posttest design with control. Twenty nurses were in the intervention group, and 16 nurses were in the control group. The intervention used was Cognitive-Behavioral Intervention (CBI), and the study compared the sense of coherence (SOC), perceived stress (PSS), and mood states of the nurses. The results found the following factors related to work stress: high workload, work environment, intensive contact with patients, and working in intensive care units with low rates of patient recovery. The T1 (early) results showed no significant difference in either group in SOC, PSS, or mood states. The T2 results (after four months) showed significant changes in the intervention group, where there was an increase in SOC and mood state and a decrease in PSS and fatigue. There was no change in the control group.

The study in Jepara, Indonesia [13] involved 33 nurses and used an explorativedescriptive design. The aim was to describe the stress experienced and coping mechanisms used by intensive care nurses. The study found that $36.4 \%$ of nurses experienced mild stress, 57.6\% experienced medium weight, and 6\% experienced severe stress. The causes of pressure were the challenges of life support provision, extensive patient monitoring, prevention of complications, and caring for patients in a critical condition. The nurses employed a range of coping mechanisms, both adaptive and maladaptive, to reduce stress. Adaptive devices included talking to other people (97\%), prayer (97\%), worship (93\%), relaxation (90.7\%), humor (97\%), and consulting a psychologist (18.2\%). 
Maladaptive mechanisms included spending time alone (30.3\%), daydreaming (54.5\%), smoking (24.3\%), drinking alcohol (12.1\%), doodling (63.6\%), feeling anger (42.2\%), and hitting objects (24.2\%).

The study in Sydney, Australia [14] included 20 nurses and 25 midwives and used a pre-test post-test intervention design. The intervention used was a modified Mindfulness-Based Stress Reduction (MBSR) program employing the following instruments: a general health questionnaire (GHQ), a SOC scale, and a Depression, Anxiety and Stress (DAAS) scale. The interventions were carried out for eight weeks. The study found that high workload led to work stress because it entailed less time for socializing and self-care. The quantitative findings indicated significant improvements in GHQ and SOC scores, and participants experienced more positive life-orientation and a decrease in stress levels. The results showed that MBSR intervention could effectively improve individual endurance and resilience in the workplace.

The study in New York, USA [15] used 55 nurses, 27 of them in an experimental intervention group and 28 of them in a control group. The intervention was a Stress Management and Resiliency Training (SMART) program implemented over 12 weeks. The study found that the main factors causing stress for nurses were workload, complex patients, interpersonal criticism, and bureaucratic obstacles. The researchers identified the following factors as additional sources of stress: increasing complexity of patients' conditions, decreasing control on the part of the nurse, role ambiguity, staff shortages, increasingly sophisticated technology, and the proliferation of competition among hospitals. Only 40 of the 55 participants (73\%) completed the study. The SMART program showed promising results, with an increase in resiliency and mental endurance in the intervention group. The intervention group experienced a decline in the sense of anxiety, which increased in the control group.

The study in Milan, Italy [16] included 30 nurses in an oncology department, 15 of them in the experimental intervention group and 15 in the control group. The intervention used was Stress Inoculation Training (SIT) delivered via mobile phones. The responses lasted four weeks and involved watching a total of eight multimedia SIT videos spread over twice-weekly sessions. The control group gives a neutral video. The study found that the main stress factors on nurses in the oncology department were dealing with difficult patients and treating patients whose condition did not improve, factors which led to increased anxiety about patients. The study found positive changes in the experimental group, namely decreased anxiety and increased the ability to cope with stress.

The six studies showed that, in nearly all the countries, the risk factors for stress in nurses included high workload, the hospital's approach to stress management, and high levels of anxiety about patients. Relatively effective individual approaches to stress management included time management, physical exercise, efficient working, relaxation exercises, a healthy lifestyle, and social support. The four most commonly used approaches for prevention of work stress were muscle relaxation, biofeedback, meditation, and cognitive restructuring. All of these helped nurses to cope with work-related stress. Some of the countries also had stress-management programs for nurses. This stress management usually took a similar form to the individualized approaches, and it was shown to reduce anxiety and stress levels in nurses and to improve nurses quality 
of life [11, 12, 14-16]. In developed countries, such as Italy, mobile phone technology has bee used as an instrument for managing stress via an individual approach [16].

\section{Conclusion}

According to the studies reviewed, there are two factors in the emergence of work stress: personal factors, and work environment or organizational factors. Work stress arises because of an imbalance between the personality characteristics of employees (personal factors) and the interpersonal and organizational characteristics of the workplace (work environment factors). Therefore, there are also two approaches to the management of work stress, namely an individual approach and an organizational approach (see Figure 2).

\section{Risk factors of work stress}

Management of work stress

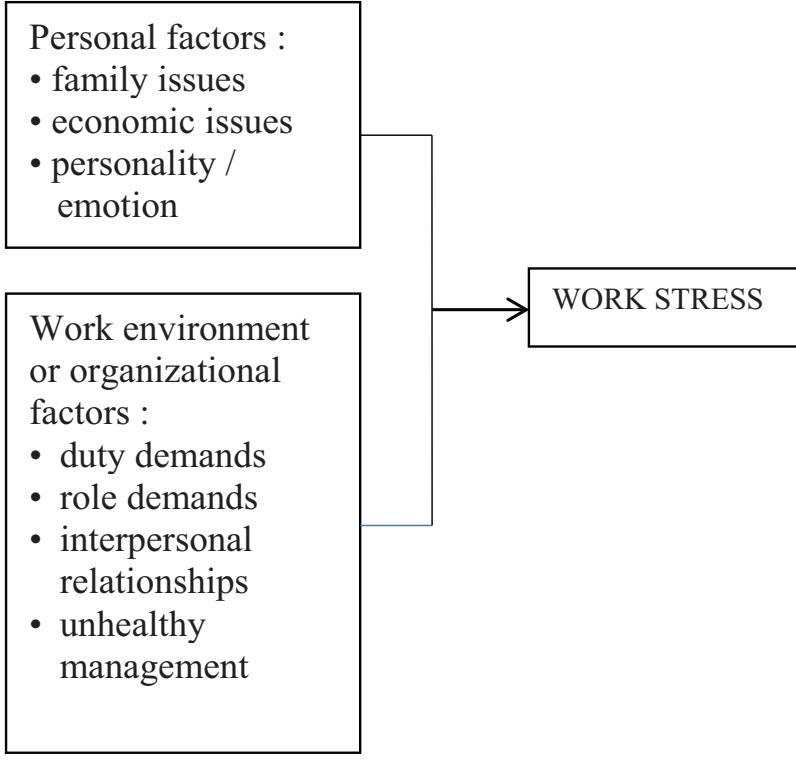

Personal approach :

- time management

- physical exercise

- relaxation exercises

- social support

Figure 2: Risk factors leading to work stress and approaches to stress management.

The management of work stress in nursing hospitals in the six countries studied used approaches similar to the personal plan. However, the methods used were different in each state and tailored to the character, nature, and culture of the country. A given process does not necessarily provide the same results in different countries.

Due to limited time and cost, the author of the present study has not found a journal that examines the organizational approach to managing stress. That approach is designed by management to eliminate or control weight by preventing or reducing work stress for the individual nurse. Strategies used in the organizational approach controlled by hospital management include: (1) improvements to processes for the selection and placement of nurses; (2) the application of principles that promote realistic goal-setting; (3) careful planning of nurses' jobs; (4) participatory decision-making; (5) implementation of an effective communication process; and (6) establishment of a fitness program for improving nurses' health. 


\section{References}

[1] Kreitner, A. \& Kinicki, R. 2005. Perilaku Organisasi. Jakarta: Salemba Empat.

[2] Lu, L., Kang, S-F., Cooper, C., \& Spector, P. 2000. Managerial Stress, Locus of Control, Job Strain in Taiwan and UK: A Comparative Study. International Journal of Stress Management 7(3),209-226.

[3] Taylor, S. 2006. Health Psychology. Los Angeles: McGraw-Hill.

[4] Tsai, Y-C., \& Lu, C-H. 2012. Factors and Symptoms Associated with Work Stress and Health-Promoting Lifestyles Among Hospital Staff: A Pilot Project in Taiwan. BMC Health Services Research 12:199.

[5] Lelyana, M. 2004. Faktor-Faktor yang Berhubungan dengan Stres Kerja pada Perawat di

[6] RS. Pelni "Petamburan" Jakarta. Depok: Universitas Indonesia.

[7] Utomo, A. 2004. Gambaran Kejadian Stres Kerja Berdasarkan Karakteristik Pekerjaan pada Perawat ICU dan UGD di RS. Mitra Keluarga Bekasi. Depok: Universitas Indonesia.

[8] Yuniarti, E. 2007. Hubungan Karakteristik Pekerjaan dengan Stres Kerja pada. Depok: Universitas Indonesia.

[9] Zeller, J. M., \& Levin, P. F. 2013. Mindfulness Interventions to Reduce Stress Among Nursing Personnel: An Occupational Health Perspective. Workplace Health and Safety 61(2), 85-89

[10] Abraham \& Shanley. 1997. Psikologi Sosial Untuk Perawat. Jakarta: EGC.

[11] Kahn, R.L. \& Byosiere, P. 1992. Stress in Organizations. Palo Alto, CA: Consulting Psychologists Press.

[12] Light, I. C., \& Bincy, R. 2012. Effect of stress management interventions on job stress among nurses working in critical care units. Nursing Journal of India, 103(6), 269-71.

[13] Orly, S., Rivka, B., Rivka, E., \& Dorit, SE. 2012. Are cognitive-behavioral interventions effective in reducing occupational stress among nurses? Applied Nursing Research 25(3), 152-57.

[14] Yusra, S., \& Susilowati, Y. (2014). Stres Dan Mekanisme Koping Perawat Di Ruang Unit Perawatan Intensif RSUD RA Kartini Jepara. Jurnal Profesi Keperawatan Krida Husada 1(1).

[15] Foureur, M., Besley, K., Burton, G., Yu, N., \& Crisp, J. 2013. Enhancing the resilience of nurses and midwives: Pilot of a mindfulness-based program for increased health, sense of coherence and decreased depression, anxiety and stress. Contemporary Nurse: A Journal for the Australian Nursing Profession 45(1), 114-25.

[16] Chesak, S., Bhagra, A., Schroeder, D., Foy, D., Cutshall, S., \& Sood, A. 2015. Enhancing resilience among new nurses: Feasibility and efficacy of a pilot intervention. Ochsner Journal 15(1), 38-44.

[17] Villani, D., Grassi, A., Cognetta, C., Toniolo, D., Cipresso, P., \& Riva, G. 2013. Self-help stress management training through mobile phones: An experience with oncology nurses. Psychological Services 10(3), 315-22. 